\title{
Exploitation of intertidal feeding resources by the Red Knot Calidris canutus under megatidal conditions (Bay of Saint-Brieuc, France)
}

\author{
Sturbois Anthony ${ }^{1,2}$, Ponsero Alain ${ }^{1}$, Desroy Nicolas ${ }^{3,{ }^{*}}$, Le Mao Patrick ${ }^{3}$, Fournier Jérôme ${ }^{4,5}$ \\ ${ }^{1}$ Réserve Naturelle de la Baie de Saint-Brieuc, site de l'étoile, 22120 Hillion, France \\ 2 VivArmor Nature, 10 boulevard Sévigné, 22000 Saint-Brieuc, France \\ ${ }^{3}$ IFREMER, Laboratoire Environnement et Ressources - Station de Dinard, 38 rue du Port Blanc, BP \\ 80108, 35801 Dinard cedex, France \\ ${ }^{4}$ CNRS, UMR 7208 BOREA, 61 rue Buffon, CP 53, 75231 Paris cedex 05, France \\ ${ }^{5}$ MNHN, Station Marine, 38 rue du Port Blanc, 35801 Dinard cedex, France \\ * Corresponding author : Nicolas Desroy, tel.: + 33223185862 ; \\ email address : nicolas.desroy@ifremer.fr
}

\begin{abstract}
:
The feeding ecology of the red knot has been widely studied across its wintering range. Red knots mainly select bivalves and gastropods, with differences between sites due to variation in prey availability. Shorebird's diet is also influenced or controlled by the tidal regime. The aim of this paper is to demonstrate the adaptation of foraging red knots to the megatidal environment. The variation in their diet during tidal cycles was studied in the bay of Saint-Brieuc, a functional unit for this species. The method used combined macrofauna, distribution of foraging birds and diet data. Comparative spatial analyses of macrofauna and distribution of foraging red knots have shown that the bay's four benthic assemblages are exploited by birds. By analysing droppings, we highlighted that bivalve molluscs are the main component of their diet, as shown in most overwintering sites. Fifteen types of prey were identified and Donax vittatus was discovered to be a significant prey item. The relative proportion of each main prey item differs significantly depending on the benthic assemblage used to forage. All available benthic assemblages and all potential feeding resources can be used during a single tidal cycle, reflecting an adaptation to megatidal conditions. This approach develops accurate knowledge about the feeding ecology of birds which managers need in order to identify optimal areas for the conservation of waders based on the areas and resources actually used by the birds.
\end{abstract}




\section{Highlights}

-We have demonstrated the adaptation of foraging Red Knots in a megatidal environment. of prey items differs significantly during the tidal cycle depending on benthic assemblages. We identified a new, significant prey for the Red Knot, Donax vittatus. - This paper suggests that a waders' diet study should include all benthic assemblages used by birds.

Keywords : Diet, Benthos, Intertidal flat, Megatidal environment, Bay of Saint-Brieuc

\section{Introduction}

The feeding ecology of red knots has received special attention, especially in terms of prey size distribution, digestibility, accessibility, profitability and intake rates. Several authors have studied the red knot's winter feeding ecology and its diet composition over a large spatial scale in New Zealand (Piersma, 1990) and in North-western Europe (Quaintenne et al., 2009; Quaintenne et al., 2011) or in more localised areas, i.e.: in the Wadden sea (Bijleveld et al., 2014; Kraan et al., 2009; van Gils et al., 2005a; Dekinga and Piersma, 1993; Zwarts et al., 1992), Wash estuary (UK) (Goss-Custard et al., 1977; Prater, 1972), Tagus estuary (Portugal) (Moreira, 1994) and on the Banc d'Arguin (Mauritania) (van den Hout et al., 2014; van Gils et al., 2013; Onrust et al., 2013; Zwarts et al., 1990).

Bivalves and gastropods are the main contributors to the red knot's diet (Folmer et al., 2010; Dekinga and Piersma, 1993; Zwarts and Blomert, 1992; Boere and Smit, 1981). Across 
Western Europe, (Quaintenne et al., 2011) showed that only six prey species (the bivalves Macoma balthica, Angulus tenuis, Cerastoderma edule, Scrobicularia plana and Abra tenuis and the gastropod Peringia ulvae) make up 98 per cent of the red knot's diet. However, dominant prey species may vary dramatically between distant sites as well as neighbouring ones (Quaintenne et al., 2014; Quaintenne et al., 2009). On a given site, the diet can vary from year to year and along the overwintering season as reported by van gils et al., 2006, Dekinga and Piersma, 1993 and Zwarts et al., 1992. Shorebirds' diet is also influenced, and indeed, controlled by the tidal regime (van gils et al., 2006; McLusky and Elliott, 2004). In intertidal flats with semi-diurnal mesotidal regimes, as in the Dutch Wadden sea, the habitats used by waders for foraging are relatively uniform (Beukema, 1976). Flocks of birds forage on a few dominant prey species. A contrario, under megatidal conditions, as in the bay of Saint-Brieuc, several distinct benthic assemblages are distributed along a continuum with regard to the bathymetric gradient (Augris and Hamon, 1996). Consequently, the diet composition in heterogeneous areas can be expected to be more diversified.

In this context, a large-scale study of the diet of red knots based on the analysis of prey items by sampling faecal droppings was conducted in the bay of Saint-Brieuc. The aim of this article is to demonstrate the adaptation of foraging activity of red knots in a megatidal environment and more particularly the variation in the diet during tidal cycles, on the scale of a presumed functional unit for the red knot.

\section{Material and methods}

\subsection{Study area}

The bay of Saint-Brieuc $\left(48^{\circ} 32 \mathrm{~N} ; 2^{\circ} 40 \mathrm{~W}\right)$ is located on the northern coast of Brittany and in the south-western part of the Normand-Breton gulf (Fig. 1). The bay encompasses $800 \mathrm{~km}^{2}$ up to the $30 \mathrm{~m}$ isobath and is subjected to an extreme megatidal regime. The tidal range varies 
between $4 \mathrm{~m}$ at neap tides and nearly $13 \mathrm{~m}$ during spring tides. The study area is divided into two large coves (Morieux and Yffiniac coves) extending over 2,900 ha of flats ranging from mud to sand. It includes the National Nature Reserve of the bay of Saint-Brieuc created in 1998 (1,140 ha) and represents a functional entity for waders. This nature reserve has been designated as an area of international importance for waders and especially for red knots (3,000 on average, i.e. $6 \%$ of the national overwintering population) during the last decade (Ponsero and Le Mao, 2011).

\subsection{Field sampling}

\subsubsection{Cartography of benthic assemblages}

The distribution of macrofauna was established from a survey conducted in October 2010. 131 sites covering 2,900 ha of intertidal area were sampled over a regular sampling network (Bijleveld et al., 2012) (Fig. 1). At each site, three replicates of sediment samples for macrobenthos analysis were collected using a $9.6 \mathrm{~cm}^{2}$ handcorer, to a depth of $25 \mathrm{~cm}$. The contents of the cores were gently sieved on site through 1-mm square mesh. The retained material was preserved for analysis in 5\% buffered formaldehyde with added rose Bengal. The macrofauna was identified to the lowest possible taxon and enumerated. Two samples of sediment (surface of $3.2 \mathrm{~cm}^{2}$, depth of $5 \mathrm{~cm}$ ) were collected from additional cores and subsequently analysed for grain size distribution and organic matter. All the sites were located by means of a GPS (Global Positioning System, Garmin Etrex Legend HCx).

\subsubsection{Location of foraging areas}

Considering the large scale of the study area (Fig. 1), observations were carried out during winters 2010/11 and 2011/12 in the coves of Yffiniac and Morieux, respectively. Birds were counted regularly during winter periods and in daytime with a telescope (Kite SP-ED 80). The 
number of feeding birds was recorded over 54 tidal cycles, under conditions which varied from neap to spring tides. For each group of birds, the species, total number of feeding and roosting individuals and the hour of the observations for information on tidal conditions were noted. The location of bird groups was calculated using a trigonometric formula based on the geographical position of the observer (determined with a Global Positioning System, Garmin Etrex Legend $\mathrm{HCx}$ ) and measurements of the bird group's distance and angle from North:

$\mathrm{X}$ bird $=\mathrm{X}$ observer $+\sin ($ angle $) \mathrm{x}$ distance, with $\mathrm{X}=$ longitude

$\mathrm{Y}$ bird $=\mathrm{Y}$ observer $+\cos ($ angle $) \mathrm{x}$ distance, with $\mathrm{Y}=$ latitude

The distance from observers and viewing angle from North were provided with laser rangefinding binoculars (Newcon LRB 3000 pro, 7x40). The model of binoculars used could measure up to $700 \mathrm{~m}$, limiting any disturbance to the birds.

\subsubsection{Sampling of droppings}

The assimilation rate of prey is quite short; less than 45 min after ingestion (Piersma, 1994). Droppings were thus collected after waiting at least 1 hour, following the recommendations of Dekinga and Piersma (1993). Acknowledging this rapid rate of assimilation, picking up droppings on high-tide roosting site is insufficient, since they only reflect the diet of the last hour of rising tide. Droppings were sampled in all existing benthic assemblages, with a strategy taking account of the tidal conditions, red knot phenology, location (Yffiniac or Morieux cove) and digestion time (Piersma, 1994).

Field sampling was performed in daytime and during ebb tide from November to March, twice a month (spring and neap tides) in each cove, avoiding disturbance to birds. A total of 30 droppings per benthic assemblage was collected each day and localised with a GPS. Each dropping was picked up carefully with a plastic tube from the surface of the sand flat to minimise the presence of sediment particles. Each sample was preserved in an $70 \%$ alcohol 
solution (De Smet et al., 2013). To prevent from sampling errors between benthic assemblages, particular attention was devoted to the movements of birds.

\subsection{Laboratory analysis}

\subsubsection{Macrofauna and sediment facies}

The macrofauna was identified to the lowest possible taxon and enumerated. The biomass of each taxon was determined as g of ASFD per $0.1 \mathrm{~m}^{2}$ (loss of weight of dry organisms after $6 \mathrm{~h}$ at $520^{\circ} \mathrm{C}$ ). After separating the flesh from the shell of bivalves, each individual's flesh ashfree dry mass $\left(\mathrm{AFDM}_{\mathrm{flesh}}\right)$ and shell dry mass $\left(\mathrm{DM}_{\text {shell }}\right)$ was determined in order to evaluate the quality of preys (Kraan et al., 2007; Piersma et al., 1993). Sediment samples were cleaned with water and following decanting was allowed during $24 \mathrm{~h}$. Sediments were then dried at $70^{\circ} \mathrm{C}$ for $24 \mathrm{~h}$ and sieved through AFNOR standard sieves, and weighed. The dried samples were combusted at $540^{\circ} \mathrm{C}$ for $4 \mathrm{~h}$ in order to determine the organic content (Hedges \& Stern, 1984).

\subsubsection{Droppings}

Bivalves and molluscs are entirely ingested and crushed in the muscular gizzard of the red knot. The composition of droppings can be defined by hard fragments, which frequently used to describe the red knot's diet (Onrust et al., 2013; Dekinga and Piersma, 1993).

After being rinsed, each dropping was sieved through a $20 \mu \mathrm{m}$ mesh size (De Smet et al., 2013) and analyzed under a binocular microscope. The relative abundance of each prey item was estimated according to a five abundance class system $(1:<5 \%, 2: 5-25 \%, 3: 25-50 \%, 4$ : $50-75 \%, 5:>75 \%)$.

\subsection{Data analysis}




\subsubsection{Macrofauna}

To define benthic assemblages, a hierarchical ascendant classification was performed using all data to distinguish between the groups of stations by applying the Bray-Curtis coefficient with a Euclidian sorting method. Multiple discriminant analysis (Legendre and Legendre, 1998) was carried out to evaluate the station groups derived from correspondence analysis and to correlate this separation with some selected variables. The first-rank species of molluscs (species of interest for red knot) were retained to characterise each identified assemblage.

\subsubsection{Droppings}

The frequency of occurrence for each prey item has been calculated globally (FOi\%) and per habitat (FOhab\%). FOi\% was calculated as follows: (number of dropping samples where the prey item $i$ is present / total number of dropping samples) x 100 .

The frequency of occurrence of prey species in each habitat (FOhab\%) was calculated, for the five class of abundance, according the formula: [(number of dropping samples where the prey species is present in the habitat and characterised by the class abundance $x$ ) / (total number of dropping samples in the habitat)] x 100

To determine differences between faecal samples on the scale of the bay, a Khi2 test was run. To test spatial changes in the relative abundance of preys in droppings, a two-way ANOVA was performed after checking the homogeneity of variance. The factors tested were abundance of prey versus benthic assemblages. This ANOVA was followed by a Tukey multiple comparisons test (Scherrer, 2007). All statistical analyses were performed with R software (R Development Core Team, 2013).

\section{Results}

\subsection{Mapping of benthic assemblages}


A total of 87 species was identified on the flats. Four distinct benthic assemblages were identified with respect to the first-rank species of molluscs (Fig. 1, Table 1): Cerastoderma edule and Scrobicularia plana dominate the assemblage of silty muds (CS, 70 ha), Cerastoderma edule and Macoma balthica the assemblage of muddy sands (CM, 250 ha), Angulus tenuis and Cerastoderma edule are predominant in the assemblage of sands (AC, 1200 ha), and Donax vittatus, Angulus tenuis and Cerastoderma edule dominate the assemblage of low level sands (DC, 1380 ha). This last assemblage area is characterised by an area with mussel beds on wooden poles, called "bouchots" covering 320 ha $(23.2 \%$ of the surface of the whole assemblage area). The main potential feeding resources for red knots (five first-rank bivalve species) are less abundant in this area (on average 81.50 ind. $\mathrm{m}^{-2} \pm$ 77.60, max 242 ind. $\mathrm{m}^{-2}$ ) compared to the rest of DC without mussel bouchots (on average 185.00 ind. $\mathrm{m}^{-2} \pm 231.00, \max 1188$ ind. $\left.\mathrm{m}^{-2}\right)$.

The emersion time of assemblages decreases from high to low water and influences the availability of prey for birds. Winter exposure time varies on average from $84 \%$ for CS to $8 \%$ for DC, $\mathrm{CM}$ and AC being respectively available on average $64 \%$ and $36 \%$ of the time (Table 2).

\subsubsection{Distribution of foraging birds}

The number of red knots during the two overwintering seasons of the study was on average 3,000 individuals and 2,100 individuals respectively in the winters of 2010/11 and 2011/12. The distribution of foraging red knots was heterogeneous on the scale of the bay, with birds foraging mainly in Yffiniac cove and in the eastern part of Morieux cove. However, flocks foraged on all identified benthic assemblages, depending on the water level. The foraging areas of red knots represented 640 ha (22\% of the intertidal area, Fig. 2). However, red knots avoided the entire mussel bouchot area and the central part of the bay. 


\subsubsection{Diversity of preys}

A total of 15 prey items were identified in all 1,001 collected droppings. Molluscs were clearly dominant as shown by FOi\% (Table 3): Cerastoderma edule (66.13\%), Angulus tenuis (50.3\%), Donax vittatus (47.6\%) Macoma balthica (43.1\%), Scrobicularia plana (14\%), Peringia ulvae (19\%) and Mytilus edule (7.4\%) (Fig. 3). Other items were represented by Pygospio elegans (1.7\%), Crustacean sp. (0.7\%), Rissoa parva (0.4\%), fishes (0.4\%), Spisula subtronquata (0.3\%), Gastropod sp. (0.3\%), Urothoe poseidonis $(0.1 \%)$ and Isopoda sp. $(0.1 \%)$

\subsubsection{Quality of preys}

Since Red knot ingests bivalves entirely, the crushing of shell fragments in the muscular gizzard induces additional energy consumption. Consequently, the quality of preys has been expressed regarding the ratio dry flesh/dry shell masses (Kraan et al., 2007; Piersma et al., 1993). Values of digestive quality are higher for Donax vittatus, Macoma balthica and Angulus tenuis (respectively 0.06, 0.06, and $\left.0.05 \mathrm{AFDM}_{\mathrm{flesh}} / \mathrm{DM}_{\text {shell }}\right)$ than for C. edule $(0.03$ $\mathrm{AFDM}_{\mathrm{flesh}} / \mathrm{DM}_{\text {shell, }}$ ) and S. plana (0.04 Table 3).

\subsubsection{Spatial changes in dropping composition}

\section{Change in prey occurrence}

Changes in droppings composition observed between benthic assemblages were highly significant $\left(\chi^{2}=1071, \mathrm{df}=18, \mathrm{p}<0.01\right)($ Table 4$)$.

In the silty mud assemblage (CS), Peringia ulvae (FOi\%= 80\%), Scrobicularia plana $(72 \%)$, and Macoma balthica (70\%) were dominant in droppings. In the muddy sand assemblage (CM), the dominant species were Cerastoderma edule (84.5\%), Angulus tenuis $(60.4 \%)$ and Macoma balthica (54.5\%). Lower on the shore, on the sand flat (AC), Cerastoderma edule 
(72.3\%) and Angulus tenuis (65\%) were the most frequently observed species in droppings. Finally, in the lowest level of sand (DC), Donax vittatus (90.9\%) and Cerastoderma edule (36.8\%) had the highest occurrences.

\section{Change in prey abundance}

The frequency of occurrence of each prey item depending on classes of abundance (FOhab\%) differed significantly (ANOVA: $\mathrm{F}_{3,11}=8.10, \mathrm{p}<0.001$ ) among the four benthic assemblages, depending on the tide (Fig. 4). During spring tides, D. vitattus represents more than $75 \%$ of preys in the assemblage DC. There were highly significant differences in dropping compositions between assemblages, except between CM and AC (Tukey's HSD test: p > 0.05). This result is probably due to the lack of difference in Cerastoderma edule's relative abundance in droppings from these two assemblages (Tukey's HSD test: $\mathrm{p}=0.49$ ).

\section{Discussion}

Benthic assemblages are distributed in belts along an inshore-offshore gradient of increasing grain-size distribution of sediments. Congruent to this gradient, the number of species increases from higher to lower belts (respectively 7 and 43 species in CS and DC). The specific composition varies over space depending on the emersion time. In the high flat, the benthic assemblage occupies a sheltered mudflat dominated by Scrobicularia plana (162.80 ind. $\mathrm{m}^{-2}$ ) and Cerastoderma edule (195.80 ind. $\mathrm{m}^{-2}$ ). In the low part of the flat, sediment and macrofauna are characteristic of a more exposed area. Clean fine to medium sands make up the sediment and Angulus tenuis (102.37 ind. $\mathrm{m}^{-2}$ ) and Cerastoderma edule (47.14 ind. $\mathrm{m}^{-2}$ ) are the dominant bivalves, with abundances reaching 605.00 ind. $\mathrm{m}^{-2}$ and 363.00 ind. $\mathrm{m}^{-2}$ respectively. At the lowest levels of the tidal flat, Donax vittatus progressively occurs $(82.40$ ind. $\mathrm{m}^{-2}$ ) with abundance reaching 1000 ind. $\mathrm{m}^{-2}$. 
The biocenotic succession observed in the bay of Saint-Brieuc corresponds to a classical pattern already described in many intertidal flats such as in the Mont Saint-Michel bay (Meziane, 1997; Thorin et al., 2001) or along the Dutch Wadden Sea (Beukema, 1989). However, in the bay of Saint-Brieuc, the prevailing hydrodynamic conditions, associated with the grain-size of sediment in the lowest levels of the flat (mean value of $205.22 \mu \mathrm{m}$ ), are responsible for the presence of Donax vittatus, which inhabits fine sand habitats (Degraer et al., 2006).

The foraging area represents 640 ha (22\% of the whole intertidal area), which is over twice as large as the first estimation made by Quaintenne et al. (2011) on the same site. Our observations clearly show that all benthic assemblages are exploited. However, the mussel bouchot area is unattractive for red knots (Fig.2). This can be explained by a deficit of trophic resources, the presence of three-dimensional structures (bouchots: wooden poles, 3 metres high) and anthropogenic disturbance (Yasué et al., 2008, Dias et al., 2008, Granadeiro et al., 2006).

The resource harvestable by red knot depends on profitability, ingestibility, digestibility and accessibility of prey (van Gils et al., 2005b; Zwarts and Blomert, 1992). The size of bivalves ingestible and profitable for red knot (Quaintenne et al., 2014; Moreira, 1994; Piersma et al., 1993) and the correspondent biomass (Table 1), explain the exploitation of the five species of bivalves by red knot in the study area.

In the bay of Saint-Brieuc, Cerastoderma edule, Angulus tenuis, Macoma balthica, Scrobicularia plana, and Peringia ulvae constitute important preys for red knots, as largely demonstrated in other sites in Europe (Folmer et al., 2010; Dekinga and Piersma, 1993; Nehls, 1992_ENREF_18; Zwarts and Blomert, 1992; Boere and Smit, 1981).

Since red knots forage on dominant prey species, non-significant differences between dropping composition in $\mathrm{CM}$ and $\mathrm{CA}$ assemblages can be explained by the predominance of 
Cerastoderma edule in these two units.

We confirmed the use of an unusual prey for the red knot, Angulus tenuis, as previously described by Quaintenne et al., 2014; Quaintenne et al., 2011 in the bay of Saint-Brieuc and Prater, 1972 in Morecambe bay. This species is easily digested (value of 5,39 \% AFDM flesh $_{\text {. }}$ $/ \mathrm{DM}_{\text {shell }}$ ) and reach in the study site (assemblage AC), approximately 600 ind. $\mathrm{m}^{-2}$. Our results confirm that Angulus tenuis contributes significantly to the diet in the bay of Saint-Brieuc, especially in AC and DC but to a lesser extent than Quaintenne et al., 2014 who suggested that red knot is specialised on this species.

Inter-annual variations in bivalve densities can contribute to explain the variation of the contribution of each prey to the diet (van gils et al., 2006).

The exploitation of Donax vitattus by Calidris canutus has not yet been described, although Donax variabilis is a well-known prey for the subspecies Calidris canutus rufa on stopover sites of the Eastern shore of Virginia, US Atlantic coast (Cohen et al., 2010). Adopting the strategy of behaving as a swash rider, Donax variabilis is present close to the water line and available as a prey for waders, whatever the tidal level considered (Levinton, 2001). Such a process has never been observed for Donax vitattus. Therefore, in Western Europe predation on this species is only possible at lowest tide levels. The specialisation on Donax vitattus by red knot, despite the presence of great abundance of Angulus tenuis, can be explained by both its high digestive quality $\left(0.06 \mathrm{AFDM}_{\mathrm{flesh}} / \mathrm{DM}_{\text {shell }}\right)$ and densities reached of approximately 1000 ind. $\mathrm{m}^{-2}$. Cyclic spatial and temporal variability due to the tide also influences the exploitation of the flat by birds (Rosa et al., 2007; van gils et al., 2006, Granadeiro et al., 2006; van Gils et al., 2005a, Fleischer, 1983) and contributes to explain the position of birds on the lowest parts of the flat during low tide.

In the bay of Saint-Brieuc, red knots are compelled to forage on highest levels of the flat during neap tide, especially on AC. However, we observed that red knots preferentially forage 
on DC assemblages as soon as the tide falls (Fig. 5) and form big flocks on areas with high densities of Donax vittatus (> 400 ind. $\mathrm{m}^{-2}, 7.2 \%$ of DC assemblage and $3.4 \%$ of the flat). These results indicate that the limited surface areas could be very attractive for foraging birds despite their short exposure time (Table 2) as reported by De Smet et al. (2013) on the Lanice conchilega reef in the bay of the Mont Saint-Michel (1\% of the total tidal flat).

\section{Conclusion}

The diet may vary dramatically between sites (Quaintenne et al., 2014; Quaintenne et al., 2009) and on the same site from year to year and along the overwintering season (Zwarts et al., 1992; Dekinga and Piersma, 1993). This study has demonstrated that diet can vary spatially with respect to benthic assemblages and temporally with respect to tidal cycles, as well as during a single tide cycle (Fig.5). During both spring and neap tides, red knots foraged on differentiated benthic assemblages and the corresponding prey species as the tide was ebbing, revealing a differential exploitation of benthic resources during tidal cycles.

With the perspective of conservation, it is necessary to preserve the succession of foraging habitats, since the red knot can adapt its diet by using alternative prey, thus coping with variations in bivalve densities.

This work is the first stage of a long-term study, the next step will be of to determine the contribution of each habitat to the energy budget of wintering redknots. The final purpose is to model the use of the bay of Saint-Brieuc, as a complete functional entity, by Redknot and others wading birds as carried out in the Wadden sea (Piersma et al., 1995)

In megatidal environments, the diversity of assemblages and therefore of feeding resources help guarantee a sustainable carrying capacity for species. They should be taken into account by marine protected area managers to identify the optimal areas for the conservation of waders. 


\section{Acknowledgments}

We sincerely thank everyone who helped us in the field or in the laboratory. Special thanks go to Leslie Verron, Emilie Bouchée, Severine Kwiecien, Clara Morey-Rubio, Alicia Simonin and Jean-Luc Simon (ONCFS, SD 22). We are very grateful to anomynous referee $\left(n^{\circ} 3\right)$ for its helpful comments which have improves the quality of this paper and for the perspectives suggested.

\section{References}

Augris, C., Hamon, D., 1996. Atlas thématique de l'environnement marin en baie de Saint-Brieuc (Côtes d'Armor). IFREMER.

Beukema, J.J., 1976. Biomass and species richness of the macrobenthic animals living on the tidal flats of the Dutch Wadden sea. Netherlands Journal of Sea Research 10(2), 236261.

Beukema, J.J., 1989. Long-term changes in macrozoobenthic abundance on the tidal flats of the western part of the Dutch Wadden Sea. Helgoländer Meeresuntersuchungen 43, 405-415.

Bijleveld, A.I., Massourakis, G., van der Marel, A., Dekinga, A., Spaans, B., van Gils, J.A., Piersma, T., 2014. Personality drives physiological adjustments and is not related to survival. Proceedings of the Royal Society B: Biological Sciences 281, 20133135.

Bijleveld, A.I., van Gils, J.A., van Der Meer, J., Dekinga, A., Kraan, C., van der Veer, H.W., Piersma, T., 2012. Designing a benthic monitoring programme with multiple conflicting objectives. Methods in Ecology and Evolution 3, 526-536.

Boere, G.C., Smit, C.J., 1981. Knot (Calidris canutus L.) in: Smit, C.J., Wolff, W.J. (eds.) (Ed.), Birds of the Wadden Sea, Rotterdam, pp. 136-145. 
Cohen, J.B., Karpanty, S.M., Fraser, J.D., Truitt, B.R., 2010. The effect of benthic prey abundance and size on red knot (Calidris canutus) distribution at an alternative migratory stopover site on the US Atlantic Coast. Journal of Ornithology 151, 355-364.

De Smet, B., Godet, L., Fournier, J., Desroy, N., Jaffré, M., Vincx, M., Rabaut, M., 2013. Feeding grounds for waders in the Bay of the Mont Saint-Michel (France): the Lanice conchilega reef serves as an oasis in the tidal flats. Marine Biology 160 (4), 751-761.

Degraer, S., Wittoeck, J., Appeltans, W., Cooreman, K., Deprez, T., Hillewaert, H., Hostens, K., Mees, J., Vanden Berghe, E., Vincx, M., 2006. The macrobenthos atlas of the Belgian part of the North Sea. Belgian Science Policy.

Dekinga, A., Piersma, T., 1993. Reconstructing diet composition on the basis of faeces in a mollusceating wader, the Knot Calidris canutus. Bird Study 40, 144-156.

Dias, M.P., Peste, F., Granadeiro, J.P., Palmeirim, J.M., 2008. Does traditional shellfishing affect foraging by waders? The case of the Tagus estuary (Portugal). Acta Oecologica 33, 188-196.

Fleischer, R.C., 1983. Relationships between tidal oscillations and Ruddy Turnstone flocking, foraging, and vigilance behavior. Condor 85, 22-29.

Folmer, E.O., Olff, H., Piersma, T., 2010. How well do food distributions predict spatial distributions of shorebirds with different degrees of self-organization? Journal of Animal Ecology 79, 747-756.

Goss-Custard, J.D., Jenyon, R.A., Jones, R.E., Newberry, P.E., Williams, R.1.B., 1977. The ecology of the Wash II. Seasonal variation in the feeding conditions of wading birds (Charadrii). Journal of Applied Ecology 14, 707-719.

Granadeiro, J.P., Dias, M.P., Martins, R.C., Palmeirim, J.M., 2006. Variation in numbers and behaviour of waders during the tidal cycle: implications for the use of estuarine sediment flats. Acta Oecologica 29, 293-300. 
Kraan, C., Piersma, T., Dekinga, A., Koolhaas, A., van der Meer, J., 2007. Dredging for edible cockles (Cerastoderma edule) on intertidal flats: short-term consequences of fisher patch-choice decisions for target and non-target benthic fauna. Journal of Marine Sciences 64, 1735.

Kraan, C., van der Meer, J., Dekinga, A., Piersma, T., 2009. Patchiness of macrobenthic invertebrates in homogenized intertidal habitats: hidden spatial structure at a landscape scale. Marine Ecology Progress Series 383, 211-224.

Legendre, P., Legendre, L., 1998. Numerical ecology. Elsevier Science, Amsterdam.

Levinton, J.S., 2001. Marine biology: function, biodiversity, ecology. Oxford University Press Oxford.

McLusky, D.S., Elliott, M., 2004. The estuarine ecosystem: ecology, threats, and management. Oxford University Press Oxford (UK).

Meziane, T., 1997. Le réseau trophique benthique en baie du Mont Saint Michel: intégration de la matière organique d'origine halophyle à la communauté à Macoma balthica. University of Rennes I, France.

Moreira, F., 1994. Diet and feeding rates of Knots Calidris canutus in the Tagus estuary (Portugal). Ardea 82, 133-133.

Nehls, G., 1992. Food selection of Knots Calidris canutus in the Wadden sea: the importance of seasonnal and annual variation of food availability. Wader Study Group Bull.

Onrust, J., de Fouw, J., Oudman, T., van der Geest, M., Piersma, T., van Gils, J.A., 2013. Red Knot diet reconstruction revisited: context dependence revealed by experiments at Banc d'Arguin, Mauritania. Bird Study 60, 287-307.

Piersma, T., 1990. Red Knots in New Zealand eat molluscs too: Preliminary diet observations at Miranda, Firth of Thames, and Farewell Spit in November 1990. Stilt 19, 3035. 
Piersma, T., 1994. Close to the edge: energetic bottlenecks and the evolution of migratory path ways in knots. University of Groningen, Groningen, The Netherlands.

Piersma, T., Hoekstra, R., Dekinga, A., Koolhaas, A., Wolf, P., Battley, P., Wiersma, P., 1993. Scale and intensity of intertidal habitat use by knots Calidris canutus in the Western Wadden Sea in relation to food, friends and foes. Netherlands Journal of Sea Research 31, 331-357.

Piersma, T., van Gils, J., De Goeij, P., van Der Meer, J., 1995. Holling's functional response model as a tool to link the food-finding mechanism of a probing shorebird with its spatial distribution. Journal of Animal Ecology 64, 493-504.

Ponsero, A., Le Mao, P., 2011. Consommation de la macro-faune invertébrée benthique par les oiseaux d'eau en baie de Saint-Brieuc. Revue d'Ecologie 66, 383-397.

Prater, A., 1972. The ecology of Morecambe Bay. III. The food and feeding habits of knot (Calidris canutus L.) in Morecambe Bay. Journal of Applied Ecology, 179-194.

Quaintenne, G., Bocher, P., Ponsero, A., Caillot, E., Feunteun, E., 2014. Contrasting benthos communities and prey selection by Red Knot Calidris canutus in three nearby bays on the Channel coast. Ardea 101, 87-98.

Quaintenne, G., van Gils, J.A., Bocher, P., Dekinga, A., Piersma, T., 2009. Diet selection in a molluscivore shorebird across Western Europe: does it show short-or long-term intake rate-maximization? Journal of Animal Ecology 79, 53-62.

Quaintenne, G., van Gils, J.A., Bocher, P., Dekinga, A., Piersma, T., 2011. Scaling up ideals to freedom: are densities of red knots across western Europe consistent with ideal free distribution? Proceedings of the Royal Society B: Biological Sciences 278, 2728-2736.

R Development Core Team, 2013. A language and environment for statistical computing. Available at http://www.R-project.org/.

Rosa, S., Granadeiro, J.P., Cruz, M., Palmeirim, J.M., 2007. Invertebrate prey activity 
varies along the tidal cycle and depends on sediment drainage: Consequences for the foraging behaviour of waders. Journal of Experimental Marine Biology and Ecology 353, 35-44.

Scherrer, B., 2007. Biostatistique. Montréal, Gaëtan Morin éditeur.

Thorin, S., Radureau, A., Feunteun, E., Lefeuvre, J.C., 2001. Preliminary results on a high east-west gradient in the macrozoobenthic community structure of the macrotidal Mont Saint-Michel bay. Continental shelf research 21, 2167-2183.

van den Hout, P.J., van Gils, J.A., Robin, F., van der Geest, M., Dekinga, A., Piersma, T., 2014. Interference from adults forces young red knots to forage for longer and in dangerous places. Animal Behaviour 88, 137-146.

van Gils, J.A., Dekinga, A., Spaans, B., Vahl, W.K., Piersma, T., 2005a. Digestive bottleneck affects foraging decisions in red knots Calidris canutus. II. Patch choice and length of working day. Journal of Animal Ecology 74, 120-130.

van Gils, J.A., Rooij, S.R., van Belle, J., van Der Meer, J., Dekinga, A., Piersma, T., Drent, R., 2005b. Digestive bottleneck affects foraging decisions in red knots Calidris canutus. I. Prey choice. Journal of Animal Ecology 74, 105-119.

van gils, J.A., Spaans, B., Dekinga, A., Piersma, T., 2006. Foraging in a tidally structured environment by red knots (Calidris canutus): ideal, but not free. Ecology 87, 1189-1202.

van Gils, J.A., van der Geest, M., Leyrer, J., Oudman, T., Lok, T., Onrust, J., de Fouw, J., van der Heide, T., van den Hout, P.J., Spaans, B., 2013. Toxin constraint explains diet choice, survival and population dynamics in a molluscivore shorebird. Proceedings of the Royal Society B: Biological Sciences 20130861.

Yasué, M., Dearden, P., Moore, A., 2008. An approach to assess the potential impacts of human disturbance on wintering tropical shorebirds. Oryx 42, 415.

Zwarts, L., Blomert, A.M., 1992. Why knot Calidris canutus take medium-sized Macoma balthica when six prey species are available. Marine Ecology Progress Series. 
Oldendorf 83, 113-128.

Zwarts, L., Blomert, A.M., Ens, B.J., Hupkes, R., van Spanje, T.M., 1990. Why do waders reach high feeding densities on the intertidal flats of the Banc d'Arguin, Mauritania? Ardea 78, 39-50.

Zwarts, L., Blomert, A.M., Wanink, J., 1992. Annual and seasonal variation in the food supply harvestable by knot Calidris canutus staging in the Wadden Sea in late summer. Marine Ecology Progress Series. Oldendorf 83, 129-139. 


\section{Legends of figures}

Fig. 1. Benthic intertidal assemblages identified in the bay of Saint-Brieuc. Points correspond to 131 stations of the regular sampling network.

Fig. 2. Foraging area used by red knot and main benthic intertidal assemblages of the bay of SaintBrieuc.

Fig. 3. Frequency of occurrence (FOi\%) of different prey species identified in droppings

Fig. 4. Frequency of occurrence of prey species identified in droppings for each class of relative abundance $(1<5 \%, 2<25 \%, 3<50 \%, 4<75 \%, 5>75 \%)$ in each habitat (FOhab\%). Spring tide (A), neap tide (B).

Fig. 5. Foraging trajectories of red knot on each sampled date: spring tide (A), neap tide (B). 
Figure 1

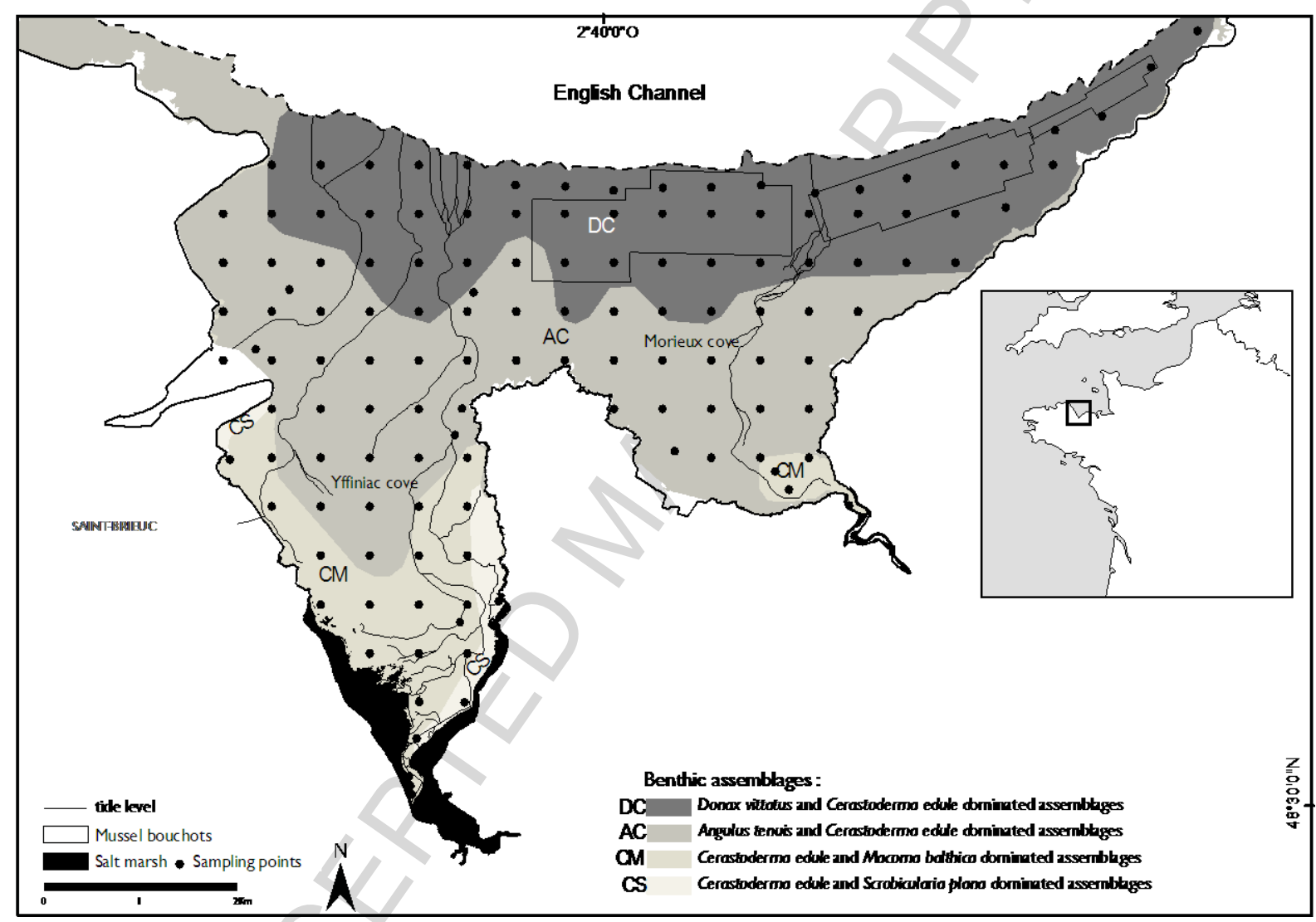


Figure 2

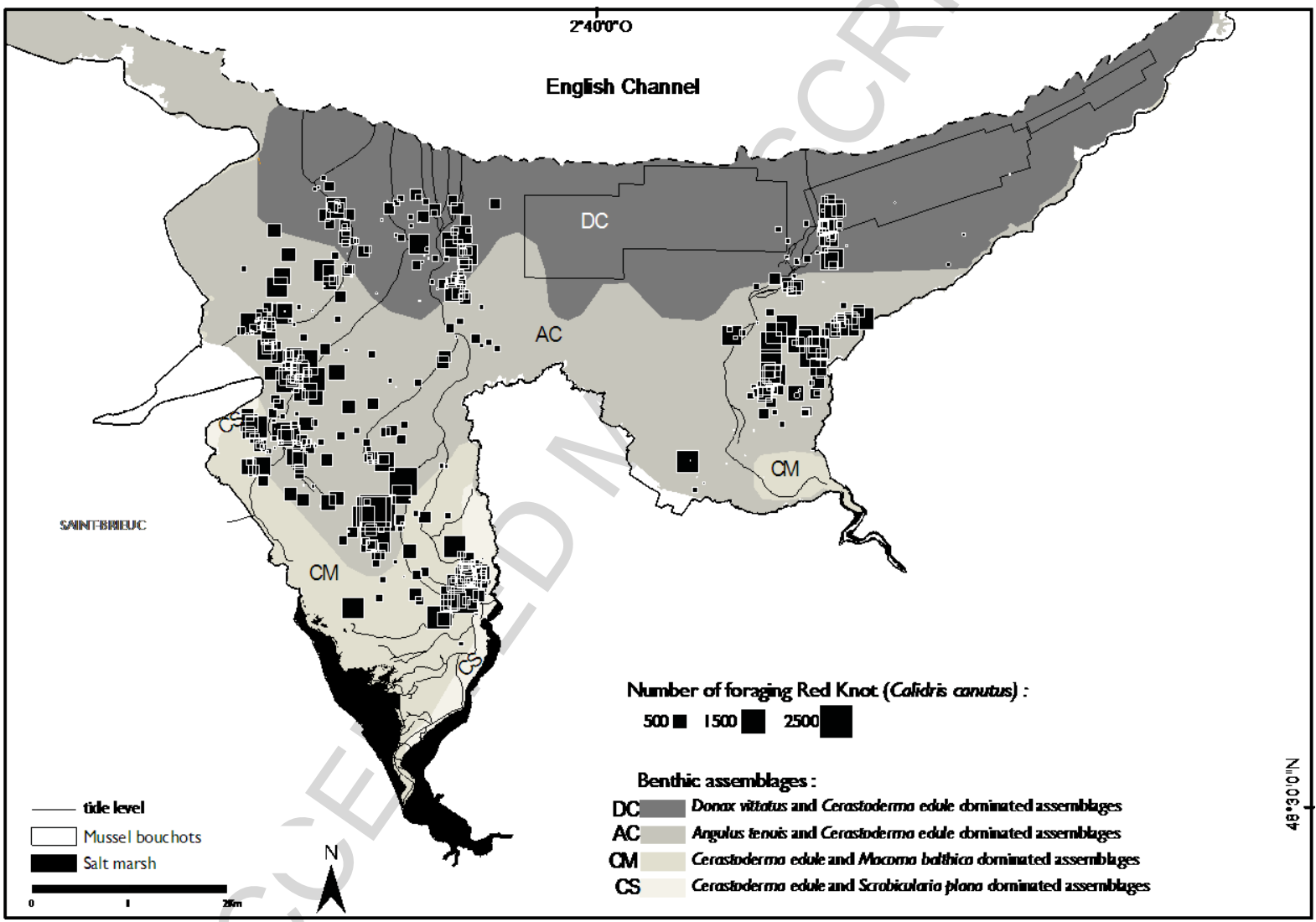


Figure 3

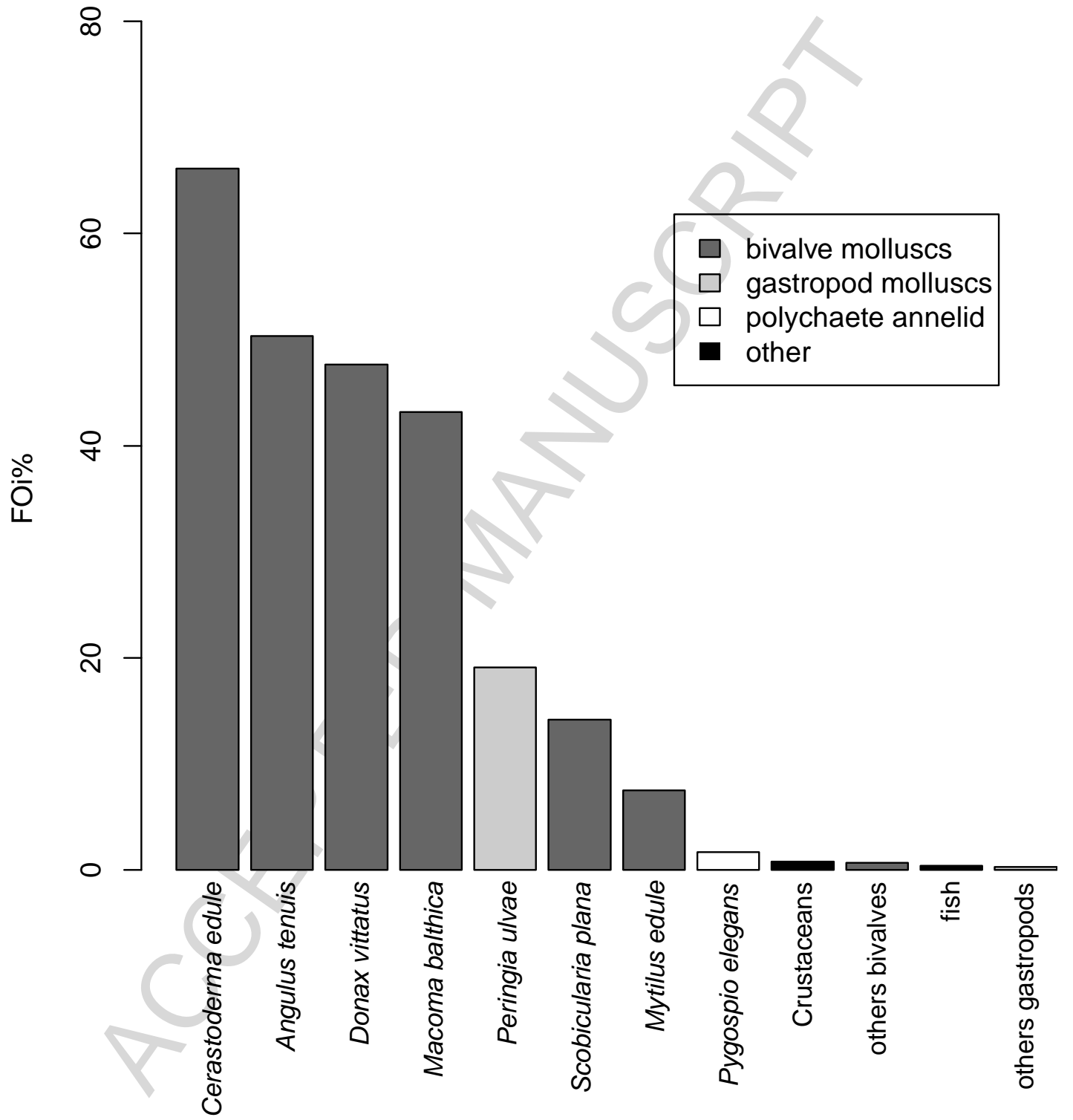


Figure 4

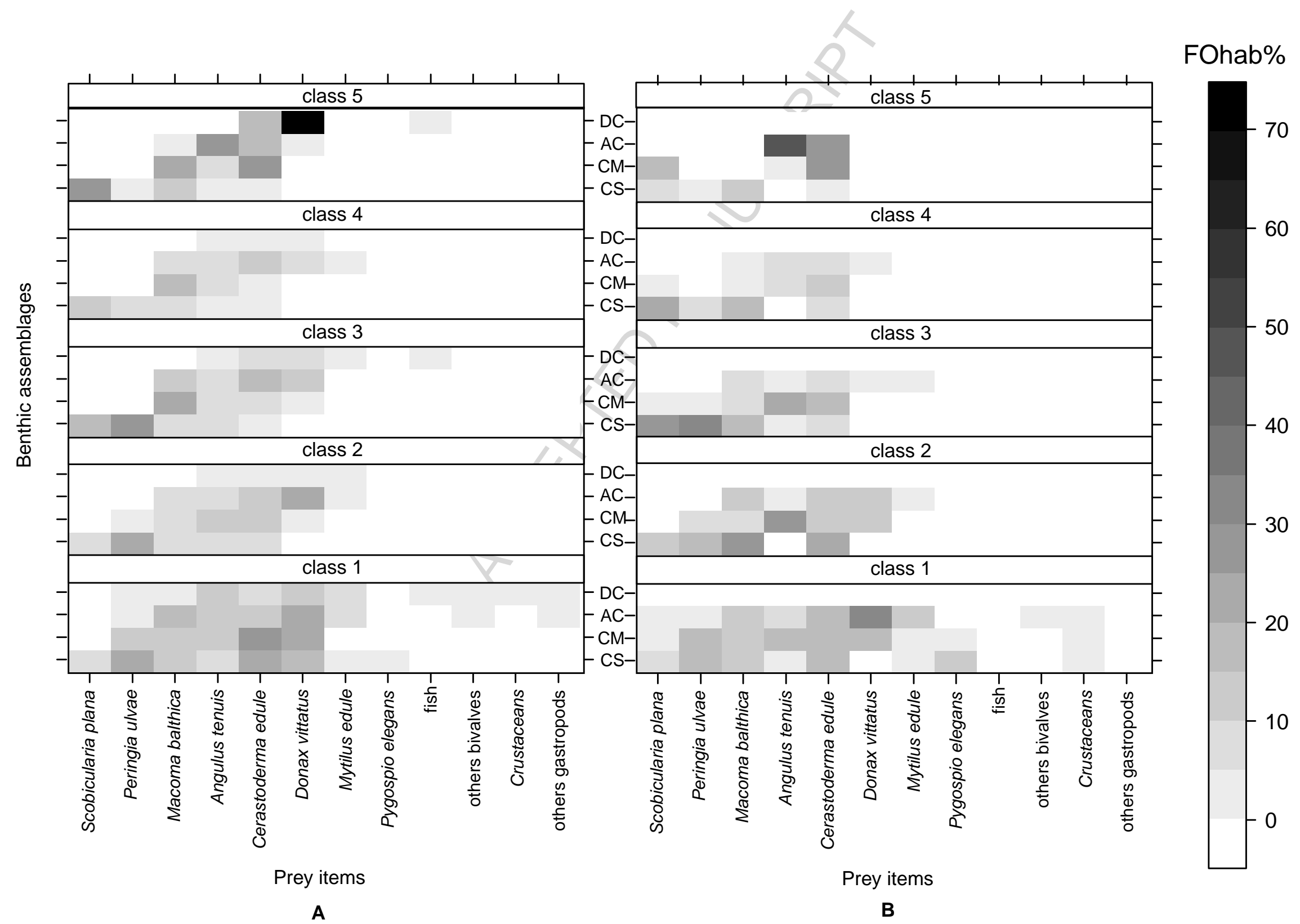


Figure 5
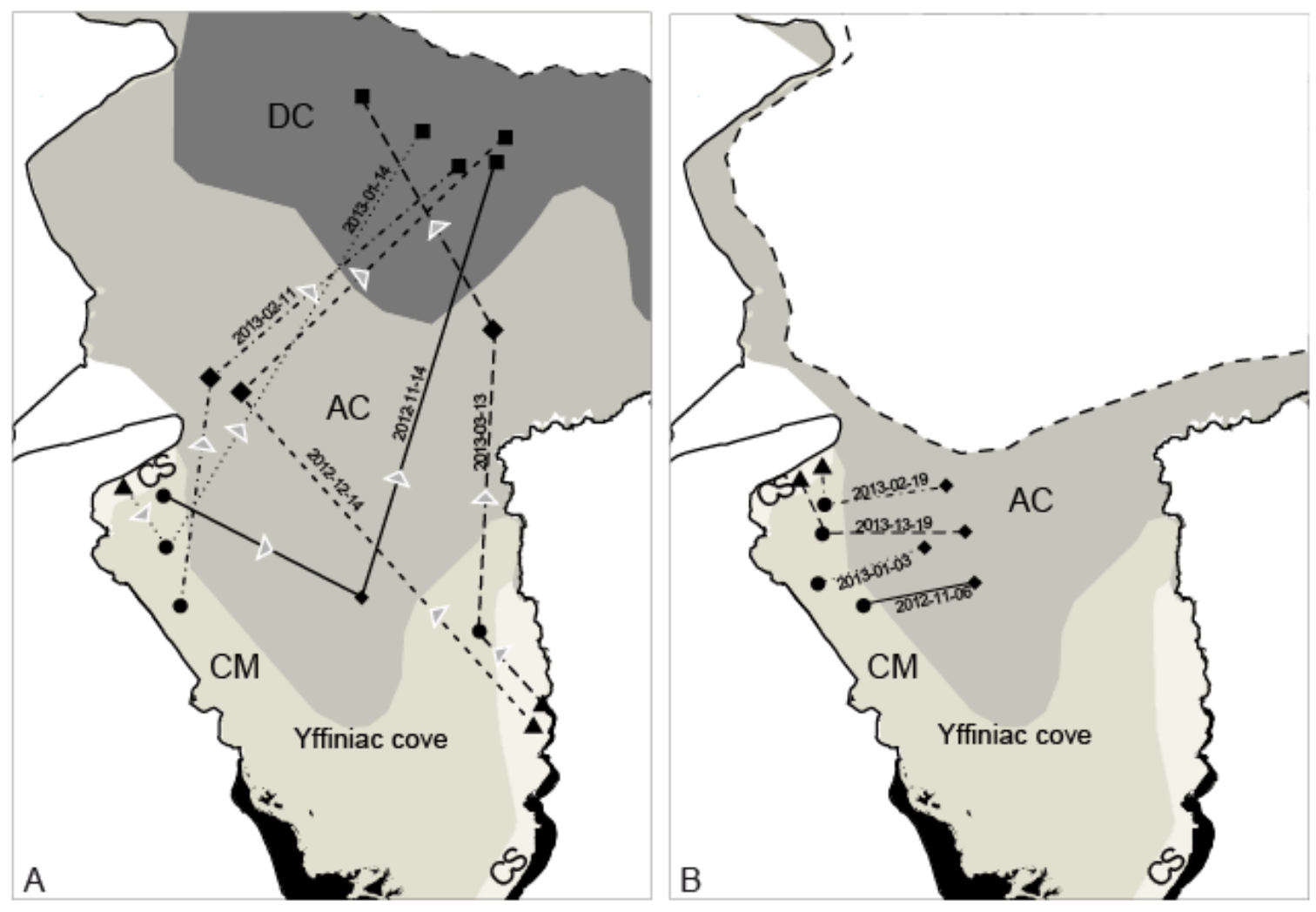


\section{Legends of tables}

Table 1. Abundance and biomass of first rank species of molluscs of interest for red knot in the different benthic assemblages and correspondent usable part (potential prey (p.p)) with regard to the size of bivalves (Angulus tenuis 4-19mm: Quaintenne et al., 2014; Cerastoderma edule: $3-17 \mathrm{~mm}$ Piersma et al., 1993; Macoma Balthica: 3 - 18 mm Piersma et al., 1993; Scrobicularia plana: 11 17mm Moreira, 1994; Donax vittatus: unknown).

Table 2. Availability of the different benthic assemblages identified in the bay of Saint-Brieuc according to exposure time: (CS) Cerastoderma edule and Scrobicularia plana dominated assemblage in silty muds, (CM) Cerastoderma edule and Macoma balthica dominated assemblage in muddy sands, (AC) Angulus tenuis and Cerastoderma edule dominated assemblage in sands, and (DC) Donax vittatus and Cerastoderma edule dominated assemblages in low level sands.

Table 3. Digestive quality of the five main preys expressed by the flesh to shell dry mass ratio

Table 4. Frequency of occurrence (FOi\%) of each prey item in dropping composition. 
Table 1

\begin{tabular}{|c|c|c|c|c|c|c|c|c|c|c|c|c|c|c|c|c|}
\hline & \multirow{2}{*}{\multicolumn{4}{|c|}{ CS }} & \multirow{2}{*}{\multicolumn{4}{|c|}{$\mathrm{CM}$}} & \multirow{2}{*}{\multicolumn{4}{|c|}{$\mathrm{AC}$}} & \multirow{2}{*}{\multicolumn{4}{|c|}{ DC }} \\
\hline & & & & & & & & & & & & & & & & \\
\hline & \multicolumn{2}{|c|}{ density $\left(\mathrm{m}^{2}\right)$} & \multicolumn{2}{|c|}{ afdw $\left(\mathrm{g} \cdot \mathrm{m}^{2}\right)$} & \multicolumn{2}{|c|}{ density $\left(\mathrm{m}^{2}\right)$} & \multicolumn{2}{|c|}{ afdw $\left(\mathrm{g} \cdot \mathrm{m}^{2}\right)$} & \multicolumn{2}{|c|}{ density $\left(\mathrm{m}^{2}\right)$} & \multicolumn{2}{|c|}{ afdw $\left(\mathrm{g} \cdot \mathrm{m}^{2}\right)$} & \multicolumn{2}{|c|}{ density $\left(\mathrm{m}^{2}\right)$} & \multicolumn{2}{|c|}{ afdw $\left(\right.$ g.m $\left.\mathrm{m}^{2}\right)$} \\
\hline & total & p.p. & total & p.p. & total & p.p. & total & & total & p.p. & total & p.p. & total & p.p. & total & p.p. \\
\hline \multirow[t]{3}{*}{ Peringia ulvae } & 187.30 & 187.30 & & & 12.16 & 12.16 & & & 0.44 & 0.44 & - & - & - & - & & - \\
\hline & 315.22 & 315.22 & & & 25.86 & 25.86 & & & 2.14 & 2.14 & & & & & & \\
\hline & 551 & 551 & & & 117 & 117 & - & & 11 & 11 & & & & & & \\
\hline \multirow[t]{3}{*}{ Angulus tenuis } & 28.60 & 28.60 & 0.22 & 0.22 & 24.50 & 23.50 & 0.12 & 0.12 & 102.37 & 93.84 & 0.44 & 0.44 & 59.4 & 38.20 & 1.39 & 0.13 \\
\hline & 64.04 & 64.04 & 0.48 & 0.48 & 69.80 & 65.76 & 0.31 & 0.31 & 129.63 & 128.1 & 0.77 & 0.76 & 92.20 & 50.59 & 0.20 & 0.19 \\
\hline & 143 & 143 & 1.08 & 1.08 & 297 & 275 & 1.28 & 1.28 & 605 & 605 & 3.66 & 3.66 & 440 & 231 & 0.94 & 0.89 \\
\hline Cerastoderma edule & 195.80 & 149.6 & 3.48 & 1.91 & 28.50 & 9.00 & 0.97 & 0.14 & 47.14 & 14.14 & 4.62 & 0.33 & 11.00 & 2.40 & 1.64 & 0.07 \\
\hline$s d$ & 240.34 & 206.20 & 4.84 & 2.61 & 64.60 & 16.15 & 2.344 & 0.31 & 83.10 & 23.70 & 8.63 & 0.54 & 31.50 & 16.40 & 3.71 & 0.49 \\
\hline $\max$ & 473 & 440 & 10.93 & 4.94 & 286 & 55 & 7.27 & 1.10 & 363 & 110 & 35.66 & 2.21 & 198 & 121 & 12.64 & 3.66 \\
\hline Macoma balthica & 24.20 & 24.20 & 0.31 & 0.31 & 10.00 & 9.00 & 0.17 & 0.12 & - & - & - & - & - & - & - & - \\
\hline$s d$ & 12.56 & 12.56 & 0.16 & 0.32 & 19.80 & 19.69 & 0.33 & 0.28 & & & & & & & & \\
\hline $\max$ & 44 & 44 & 0.84 & 0.84 & 77 & 77 & 1.20 & 1.20 & & & & & & & & \\
\hline Donax vittatus & - & - & - & - & & - & - & - & 6.73 & 6.73 & 0.16 & 0.16 & 82.40 & 82.40 & 0.21 & 0.21 \\
\hline$s d$ & & & & & & & & & 17.50 & 17.50 & 0.43 & 0.43 & 174.50 & 174.50 & 0.62 & 0.62 \\
\hline $\max$ & & & & & & & & & 99 & 99 & 2.38 & 2.38 & 1089 & 1089 & 3.85 & 3.85 \\
\hline Scrobicularia plana & 162.84 & 22.22 & 7.54 & 0.18 & 7.50 & 1.50 & 0.33 & 0.02 & - & - & - & - & - & - & - & - \\
\hline$s d$ & 364.34 & 49.20 & 16.87 & 0.41 & 24.30 & 5.14 & 1.178 & 0.06 & & & & & & & & \\
\hline $\max$ & 814 & 110 & 37.72 & 0.91 & 88 & 22 & 5.24 & 0.24 & & & & & & & & \\
\hline \multirow[t]{3}{*}{ bivalves mean } & 411.44 & 224.62 & 11.55 & 2.62 & 70.50 & 43.00 & 1.59 & 0.40 & 156.24 & 114.71 & 5.22 & 0.93 & 152.8 & 123.00 & 3.24 & 0.41 \\
\hline & 353.00 & 218.00 & 15.90 & 2.81 & 111 & 78.5 & 2.81 & 0.66 & 153.00 & 132.00 & 8.74 & 1.08 & 202.00 & 186.00 & 4.03 & 1.07 \\
\hline & 858 & 462 & 38.60 & 5.97 & 374 & 308 & 8.17 & 2.16 & 627 & 627 & 36.60 & 4.59 & 1188 & 1188 & 16.1 & 7.64 \\
\hline
\end{tabular}


Table 2

\begin{tabular}{lccccc}
\hline $\begin{array}{c}\text { Benthic } \\
\text { assemblage }\end{array}$ & $\begin{array}{c}\text { Surface } \\
\text { (ha) }\end{array}$ & $\begin{array}{c}\text { height of land } \\
\text { emergence (m) }\end{array}$ & $\begin{array}{c}\text { duration of } \\
\text { exposure will } \\
\text { average per day } \\
\text { (h) }\end{array}$ & sd & $\%$ \\
\hline CS & 70 & 9 & 20.2 & 2.26 & 84 \\
CM & 250 & 7.5 & 15.4 & 0.89 & 64 \\
AC & 1200 & 4.5 & 8.5 & 0.82 & 36 \\
DC & 1380 & $<4$ & 3.5 & 1.43 & 8 \\
\hline
\end{tabular}


Table 3

\begin{tabular}{lcc}
\hline & AFDMFlesh/DMShell & $\mathrm{sd}$ \\
\hline Cerastoderma edule & 0.03 & 4.55 \\
Scrobicularia plana & 0.04 & 1.33 \\
Angulus tenuis & 0.05 & 1.93 \\
Macoma balthica & 0.06 & 2.18 \\
Donax vittatus & 0.06 & 1.28 \\
\hline
\end{tabular}


Table 4

\begin{tabular}{|c|c|c|c|c|c|c|c|c|c|c|c|c|}
\hline $\begin{array}{c}\text { Benthic } \\
\text { assemblage }\end{array}$ & Scro-pla & Per-ulv & Mac-bal & Ang-ten & Cer-edu & Don-vit & Myt-edu & Pygo-ele & fish & other-biv & Crus & other-gast \\
\hline $\mathrm{CS}$ & 72.00 & 80.00 & 70.00 & 20.00 & 42.67 & 11.33 & 2.67 & 8.00 & - & - & 0.67 & - \\
\hline $\mathrm{CM}$ & 13.75 & 21.25 & 54.58 & 60.42 & 84.58 & 30.42 & 0.42 & 2.08 & - & - & 1.67 & - \\
\hline $\mathrm{AC}$ & 0.21 & 3.97 & 39.96 & 65.06 & 72.38 & 55.65 & 12.34 & - & - & 1.05 & 0.42 & 0.21 \\
\hline DC & - & 0.75 & 3.76 & 13.53 & 36.84 & 90.98 & 8.27 & - & 3.01 & 1.5 & 0.75 & 1.5 \\
\hline Total & 14.19 & 19.08 & 43.16 & 50.35 & 66.13 & 47.65 & 7.49 & 1.7 & 0.4 & 0.7 & 0.8 & 0.3 \\
\hline
\end{tabular}

